Tersedia online di: http://ejournal-balitbang.kkp.go.id/index.php/jra

\title{
PERKEMBANGAN GONAD DAN PERTUMBUHAN IKAN NILEM BETINA ALL FEMALE HASIL FERTILISASI JANTAN NEOMALE
}

\author{
Jojo Subagja\#, Deni Radona, dan Anang Hari Kristanto
}

Balai Riset Perikanan Budidaya Air Tawar dan Penyuluhan Perikanan

(Naskah diterima: 19 Januari 2017; Revisi final: 2 Maret 2017; Disetujui publikasi: 20 Maret 2017)

\begin{abstract}
ABSTRAK
Dalam memenuhi kebutuhan produksi diperlukan ketersediaan induk betina yang unggul. Pembentukan all female berasal dari pemijahan jantan fungsional (aplikasi hormon metil testosteron) hasil secara pool gamet dengan betina normal. Penelitian ini bertujuan mengevaluasi perkembangan gonad dan pertumbuhan ikan nilem betina (all female) hasil fertilisasi jantan fungsional (neomale). Pemeliharaan ikan uji all female dilakukan dalam jaring polyetilene berukuran $2 \mathrm{~m} \times 2 \mathrm{~m} \times 2 \mathrm{~m}$ dengan kepadatan 60 ekor di Instalasi Penelitian Toksikologi dan Lingkungan Budidaya Cibalagung Bogor. Selama enam bulan pemeliharaan ikan diberi pakan komersil berupa pelet dengan kandungan protein $28 \%$ sebanyak $5 \%$ dari bobot total dengan frekuensi tiga kali sehari (pagi, siang, dan sore). Pengamatan pertumbuhan dan pengambilan sampel ikan untuk materi histologi dilakukan setiap bulan. Hasil penelitian menunjukkan ikan all female dapat tumbuh dan berkembang normal. Secara statistik pertumbuhan ikan all female berbeda nyata $(P<0,05)$ dibandingkan dengan kontrol, dengan nilai panjang $(14,2 \pm 2,35 \mathrm{~cm})$, bobot $(28,9 \pm 2,24 \mathrm{~g})$, dan pertumbuhan bobot relatif $(58,79 \%$. Pada perkembangan kematangan gonad ikan all female masuk pada tingkat III dan IV dengan nilai IGS sebesar 20,2\%serta tidak ditemukan gonad intersex.
\end{abstract}

\section{KATA KUNCl: ikan nilem; all female; neomale; gonad; pertumbuhan}

ABSTRACT: Gonadal development and growth rate of all female Bonylip barb produced from the breeding of neomale and normal female. By: Jojo Subagja, Deni Radona, and Anang Hari Kristanto

In order to supply sufficient seed for grow out industry, the availability of female broodstock takes the priority in hatchery operations. In order to reach that objective, all female seed batch for potential future broodstock could be produced by breeding functional males (induced with methyl testosterone hormone application) with a pool gametes of normal females. This study was aimed to evaluate the gonadal development and growth of all female Bonylip barb produced from fertilization of neomale and normal females. All the females were reared in polyethylene net cages $(2 \mathrm{~m}$ $\times 2 \mathrm{~m} \times 2 \mathrm{~m}$ in size) with a stocking density of 60 individuals/cage. The trial was conducted at the Cibalagung Toxicology and Environmental Research Station, Bogor. The fish were reared for six months and fed three times daily with commercial pellets (crude protein of $28 \%$ ) as much as $5 \%$ of the total weight. Observations on the growth and fish sample collections for histology analysis were conducted every month. The results showed that all female fish were able to grow and develop normally. Statistically, the growth of all female was significantly different $(P<0.05)$ compared to the control, with the length size of $14.2 \pm 2.35 \mathrm{~cm}$ and weight of $28.9 \pm 2.24 \mathrm{~g}$ and relative weight gain of $58.79 \%$ In terms of gonadal development, all female fish reached stage III and IV with IGS value of $20.2 \%$ and no inter-sex gonad observed.

\section{KEYWORDS: bonylip barb; all female; neomale; gonad; growth}

\section{PENDAHULUAN}

Dalam memenuhi penyediaan bahan baku olahan yang berbasis telur ikan nilem diperlukan produksi ikan nilem yang tinggi dan berkesinambungan, serta didukung oleh ketersediaan benih yang cukup baik

\# Korespondensi: Balai Riset Perikanan Budidaya Air Tawar dan Penyuluhan Perikanan. Jl. Sempur No. 1, Bogor 16154, Indonesia. Tel. + (0251) 8313200

E-mail: subagja.j@gmail.com kuantitas maupun kualitasnya. Kebutuhan benih tersebut akan sangat tergantung pada kecukupan tersedianya induk unggul. Dalam sistem produksi benih akan diperlukan jumlah induk betina yang lebih banyak dibanding ikan jantan. Selain itu, ikan nilem diduga memiliki dimorfisme seksual terkait pertumbuhan, ikan nilem betina tumbuh lebih cepat dibandingkan dengan jantan. Pada umumnya nisbah kelamin jantan dan betina kelompok ikan telestoi 
memiliki nilai tidak jauh berbeda dari rasio 1:1. Lebih lanjut, Junior (2004) menyatakan ikan nilem bersifat heterogamet. Secara alami populasi ikan yang sifatnya heterogamet memiliki komposisi seimbang antara jantan dan betina.

Untuk menunjang keberhasilan produksi dan peningkatan kuantitas induk betina, diperlukan strategi dalam meningkatkan induk betina secara kuantitas. Produksi ikan betina dengan proporsi yang lebih tinggi dibandingkan jantan dapat ditempuh melalui manipulasi genom dan hormonal (Pongthana et al., 1999; Sutrisno, 1996). All female yang dibentuk dengan manipulasi hormonal menggunakan hormon testosteron sudah dilakukan sejak 1991 pada ikan rainbow trout Oncorhynchus mykiss (Olito \& Brock, 1991), sedangkan dengan manipulasi genom (diploid dan triploid) sudah dilakukan sejak tahun 1996 pada ikan salmon Salmon salar (Carthy et al., 1996). Pembentukan all female pada ikan dengan manipulasi hormon memiliki beberapa kelemahan antara lain sulit dikontrol bila diaplikasikan oleh pembudidaya, polutan yang dihasilkan mengandung hormon berbahaya untuk lingkungan, dan reaksi negatif konsumen berupa penolakan terhadap produk yang dihasilkan. Kondisi terkini penggunaan hormon-hormon estrogen sudah mulai dibatasi karena diduga residu hormon tersebut menjadi salah satu bahan pencemar lingkungan (endocrine destruction agent) dan bersifat karsiogenik pada manusia (Ariyanto et al., 2010).

Pembentukan all female pada ikan yang ramah lingkungan yaitu dengan metode manipulasi genom, dengan cara melakukan pemijahan antara jantan fungsional dengan betina normal. Jantan fungsional (neomale) diperoleh dari proses jantanisasi melalui aplikasi hormon metil testosteron. Pada penelitian Subagja et al. (2015), jantanisasi menggunakan metil testosteron (dosis $500 \mu \mathrm{g} / \mathrm{L}$ ) pada ikan nilem dapat menghasilkan individu jantan neomale sebesar $86,67 \%$ dengan metode perendaman dan $96,67 \%$ dengan metode oral. Selanjutnya, dari hasil pemijahan antara jantan neomale dengan betina normal dapat menghasilkan betina sebesar $100 \%$ namun performa gonad ikan belum diketahui secara fungsi. Penelitian ini bertujuan untuk mengevaluasi keberhasilan program all female (hasil fertilisasi jantan fungsional neomale) dengan melihat keragaan perkembangan go nad dan performa pertumbuhannya.

\section{BAHAN DAN METODE}

Penelitian ini dilakukan di Instalasi penelitian Toksikologi dan Lingkungan Budidaya Cibalagung, merupakan unit pelaksana teknis dari Balai Riset Perikanan Budidaya Air Tawar dan Penyuluhan Perikanan, Bogor.

\section{Induk Ikan Nilem}

Ikan nilem yang digunakan berupa induk yang berukuran $301 \pm 67 \mathrm{~g}$, sebanyak 10 ekor jantan fungsional dan 10 ekor betina normal. Proses pembentukan jantan fungsional mengacu pada Subagja et al. (2015). Induk ikan nilem yang digunakan merupakan ikan koleksi dari Balai Riset Perikanan Budidaya Air Tawar dan Penyuluhan Perikanan.

\section{Pembentukan Ikan Nilem All female}

Ikan nilem all female merupakan hasil dari produksi massal ikan betina homogamet (pemijahan antara delapan ekor jantan fungsional hasil secara pool gamet dengan tiga ekor betina normal). Induk yang digunakan merupakan hasil seleksi dari 20 ekor ikan (10 ekor jantan fungsional dan 10 ekor betina normal) yang terlebih dahulu dilakukan pematangan gonad dengan memberi pakan yang mengandung protein tinggi $(32 \%$ sebanyak $2 \%$ dari bobot total. Pemberian pakan dilakukan tiga kali sehari (pagi, siang, dan sore). Seleksi induk dilakukan dengan penentuan tingkat kematangan gonad secara biopsi menggunakan kateter. Pemijahan dilakukan dengan teknologi induced breeding (Radona et al., 2011).

\section{Perkembangan Gonad}

Pengamatan gonad dilakukan pada tiga sampel per populasi (all female dan kontrol) setiap 30 hari selama enam bulan pemeliharaan (ikan nilem berumur 2-7 bulan). Pertumbuhan gonad diamati dengan menghitung indeks gonad somatik (IGS) dan histologi menggunakan acetocarmin. Selain itu, ditentukan tingkat perkembangan gonad ikan dengan mengacu Effendie (2002), yaitu: TKG-I (immature; dara), TKG-II (developing; dara berkembang), TKG-III (maturing/ripening; pematangan), TKG-IV (mature/ripe/gravid; matang), TKG-V (spent; salin).

\section{Performa Pertumbuhan}

Parameter pertumbuhan yang diamati meliputi: pertumbuhan panjang $(\mathrm{cm})$, pertumbuhan bobot $(\mathrm{g})$, dan pertumbuhan bobot relatif (\%). Ikan nilem all female yang digunakan berupa benih berukuran $2-3 \mathrm{~cm}$. Pemeliharaan dilakukan pada jaring polyetilene berukuran $2 m \times 2 m \times 2 m$ dengan kepadatan 60 ekor selama enam bulan. Selama pemeliharaan benih diberi pakan berupa pelet komersil dengan kandungan protein 28\%(Djajasewaka et al., 2005), sebanyak 5\%dari bobot total dengan frekuensi tiga kali sehari, pagi (08.00 WIB), siang (14.00 WIB), dan sore (16.00 WIB). Pertumbuhan panjang, bobot, dan pertumbuhan bobot relatif diamati setiap 30 hari. Sampling pertumbuhan dilakukan dengan mengukur panjang dan bobot individu sebanyak 30 ekor dari total populasi. 
Paramater yang diamati dihitung berdasarkan rumus menurut Effendie (2002).

\section{Kualitas Air}

Pengamatan kualitas air pada media pemeliharaan dilakukan pada awal dan akhir pemeliharaan dengan selang tiga jam selama 24 jam. Parameter suhu $\left({ }^{\circ} \mathrm{C}\right)$, $\mathrm{pH}$, dan oksigen terlarut $(\mathrm{mg} / \mathrm{L})$ diukur langsung saat pengamatan menggunakan M ulti Parameter Water Quality Meter, sedangkan nitrat $(\mathrm{mg} / \mathrm{L})$ dan nitrit $(\mathrm{mg} / \mathrm{L})$ diamati di laboratorium Uji Balai Riset Perikanan Budidaya Air Tawar, Bogor yang sudah terakreditasi ISO 17025:2008 (LP-711 IDN).

\section{Analisis Data}

Perkembangan gonad dianalisis secara deskriptif. Data pertumbuhan ikan (panjang, bobot, dan pertumbuhan bobot relatif) yang diperoleh kemudian ditabulasi dan dianalisis statistik menggunakan bantuan program SPSS versi 18. Uji banding keragaman pertumbuhan dianalisis dengan analisis uji T dengan selang kepercayaan 95\% Untuk data parameter air dianalisis secara kualitatif.

\section{HASIL DAN BAHASAN}

\section{Performa Pertumbuhan}

Pertumbuhan panjang, bobot, dan pertumbuhan bo bot relatif ikan nilem all femalehasil pemijahan jantan fungsional dengan betina homogamet selama enam bulan pemeliharaan disajikan pada Gambar 1, 2, dan 3.
Dari hasil pengamatan pertumbuhan menunjukkan ikan nilem all female memiliki performa yang terbaik dibandingkan ikan nilem kontrol dengan nilai pertumbuhan panjang $(14,2 \pm 2,35 \mathrm{~cm})$, bobot $(28,9$ $\pm 2,24 \mathrm{~g})$, dan pertumbuhan bobot relatif $(58,79 \%$. Berdasarkan uji statistik, nilai pertumbuhan panjang dan bobot pada ikan nilem all female tersebut menunjukkan nilai yang berbeda $(P<0,05)$ dengan ikan nilem kontrol. Hal ini bisa mengindikasikan bahwa ikan nilem memiliki dimorfisme seksual terkait pertumbuhan. Ikan betina memiliki karakter pertumbuhan yang lebih cepat dibandingkan dengan ikan jantan. Dimorfisme seksual pada ikan betina juga terjadi pada ikan papuyu Anabas testudineus yang pertumbuhan bobotnya $48 \%$ lebih tinggi daripada jantan (Hidayat et al., 2016), pada ikan mas Cyprinus carpio yang memiliki bobot panen 29,7\%lebih tinggi daripada populasi heteroseks (Kocour et al., 2005), dan pada jenis krustase seperti udang windu Penaeus monodon yang pertumbuhannya lebih cepat $20 \%$ daripada udang jantan (Gopal et al., 2010). Tren pertumbuhan ikan nilem yang terjadi menunjukkan performa terbaik pada pemeliharaan bulan ke-5. Kondisi ini menandakan bahwa ikan bertambah gemuk yang disebabkan bertambahnya volume gonad. Pada pengamatan sampel gonad di bulan ke-5, ovari bertambah besar dan peningkatan bobot. Selain itu, dari uji acetocarmin memperlihatkan oosit mengalami peningkatan diameter.

\section{Perkembangan Gonad}

Hasil dari pengamatan perkembangan gonad dengan menggunakan uji acetocarmin pada ikan nilem

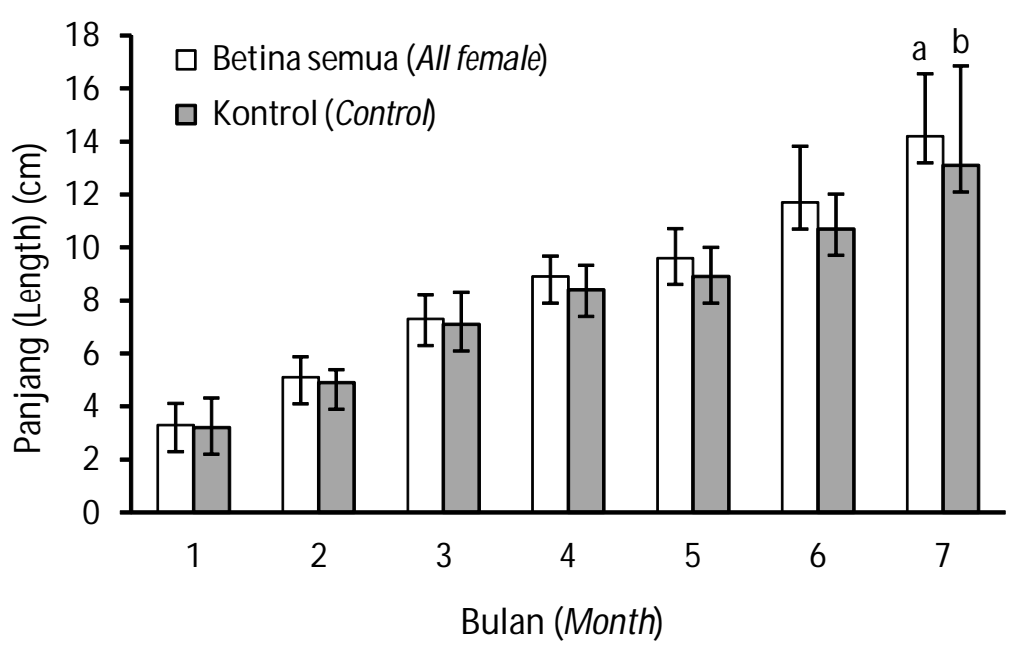

Gambar 1. Pertumbuhan panjang ikan nilem all female selama enam bulan pemeliharaan [Keterangan: superskrip yang berbeda pada diagram batang menunjukkan adanya perbedaan nyata menurut Uji Duncan $(P<0,05)$ ].

Figure 1. The growth in body length of all female Bonylip barb reared for six months [Remarks: different superscripts on the bar chart indicate significant difference $(P>0.05)]$. 


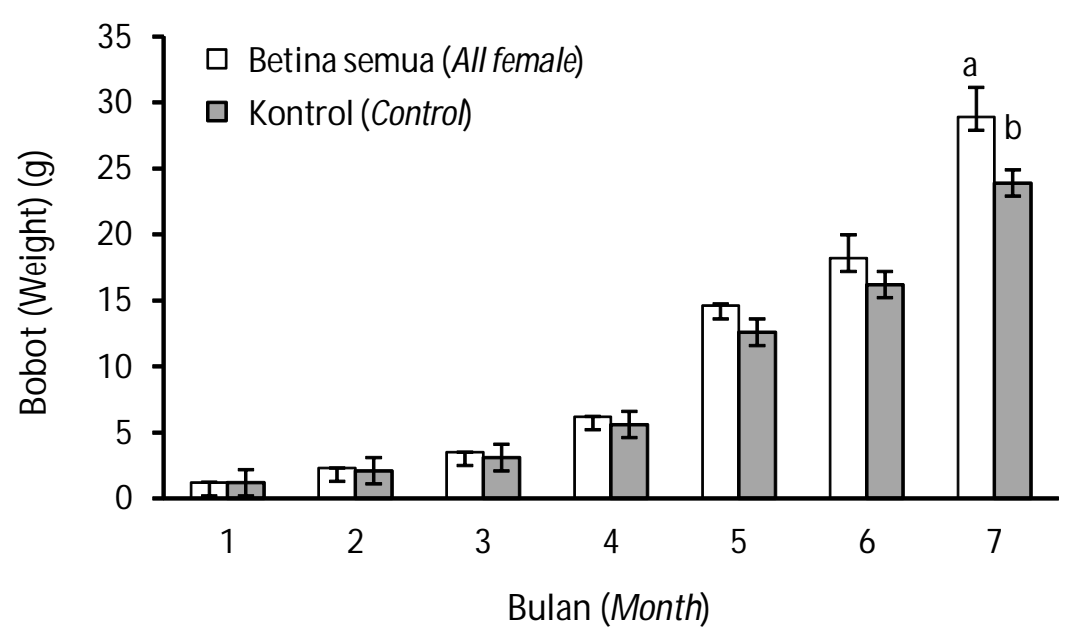

Gambar 2. Pertumbuhan bobot ikan nilem all female selama enam bulan pemeliharaan [Keterangan: superskrip yang berbeda pada diagram batang menunjukkan adanya perbedaan nyata menurut Uji Duncan $(P<0,05)$ ].

Figure 2. The growth in body weight of all female Bonylip barb reared for six months [Remarks: different superscripts on the bar chart indicate significant difference $(P>0.05)]$.

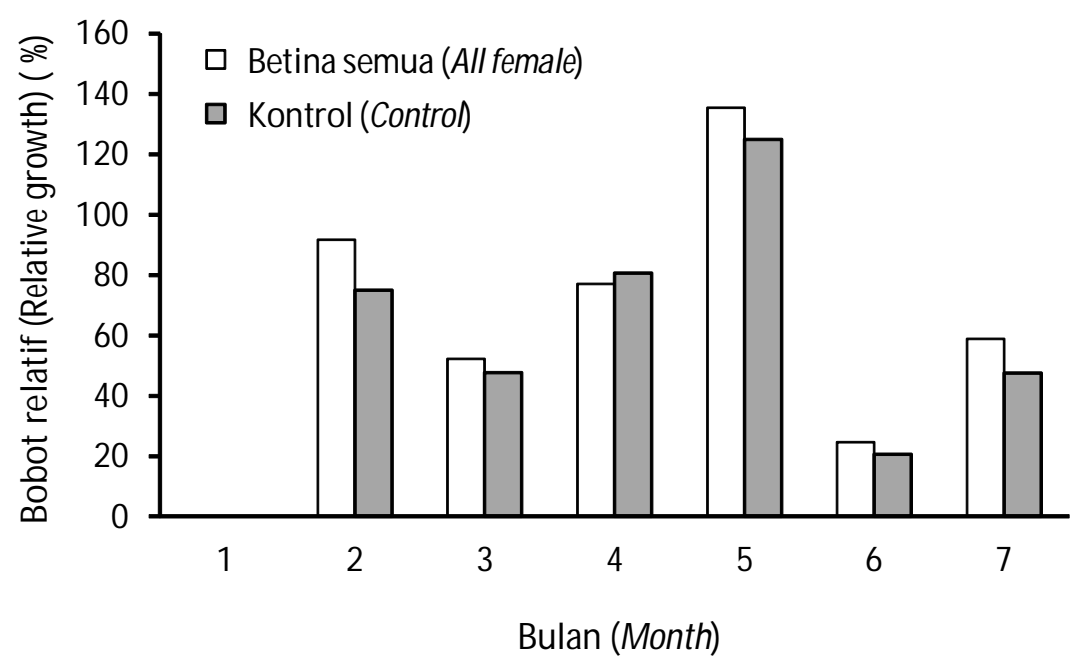

Gambar 3. Pertumbuhan bobot relatif ikan nilem all female selama enam bulan pemeliharaan.

Figure 3. The relative growth of all female bonylip barb reared for six month.

all female sesuai ukuran dan waktu sampling tertera dalam Tabel 1 dan 2.

TKG menunjukkan suatu tingkatan kematangan seksual ikan. Sebagian besar hasil metabolisme dari ikan tersebut digunakan selama fase perkembangkan gonad. Umumnya pertambahan berat gonad pada ikan betina sebesar 10\%25\%dari bobot badan, sedangkan untuk ikan jantan berkisar antara 5\%10\% (Effendie, 2002). Hal tersebut sejalan dengan kondisi ikan uji di mana pada pengamatan ke-4 bobot ikan uji memperlihatkan peningkatan, dan diikuti dengan pertumbuhan relatif mencapai $135,48 \%$ Secara umum pertumbuhan TKG berhubungan erat dengan karakteristik kelamin sekunder, ikan betina lebih besar dibandingkan dengan ikan jantan (Bhatta et al., 2012).

Dalam menentukan tingkat kematangan gonad memiliki variasi dan berbagai versi. Hal tersebut terjadi karena sifatnya yang subjektif, perbedaan tingkat pengamatan, dan perbedaan waktu. Dari pengamatan secara visual pada setiap pengambilan sampel per populasi ikan nilem all female tidak ditemukan gonad intersex. Tingkat kematangan gonad ikan nilem all female selama enam bulan pemeliharaan menunjukkan perkembangan gonad yang 
Tabel 1. Perkembangan gonad ikan nilem all female selama enam bulan pengamatan

Table 1. Gonadal development of all female bonylip barb for six months of observation

\begin{tabular}{|c|c|c|}
\hline \multirow{2}{*}{$\begin{array}{l}\text { Pengamatan } \\
\text { Observation }\end{array}$} & \multicolumn{2}{|c|}{$\begin{array}{l}\text { Perkembangan ikan dan gonad ikan nilem all female } \\
\text { Gonadal and fish development of all female bonylip barb }\end{array}$} \\
\hline & $\begin{array}{l}\text { Ikan sebelum diambil gonad } \\
\text { Fish before gonad taken }\end{array}$ & $\begin{array}{l}\text { Gonad ikan all female setelah difiksasi } \\
\quad \text { acetocarmin } \\
\text { All female gonad after fixated with acetocarmin }\end{array}$ \\
\hline \multicolumn{3}{|l|}{$\begin{array}{l}\text { Sampling } \\
\text { kedua } \\
\text { The second } \\
\text { sampling }\end{array}$} \\
\hline & $\begin{array}{l}\text { Ikan uji sudah mencapai panjang standar } \\
\text { 4,0-5,4 cm } \\
\text { The test fish has reached } 4.0-5.4 \mathrm{~cm} \text { in } \\
\text { standard length }\end{array}$ & $\begin{array}{l}\text { Gonad betina umur dua bulan sudah tampak } \\
\text { butiran oogonia (TKG I) } \\
\text { The female gonads at two months old, showing the } \\
\text { form of oogonia ( } 1^{\text {st }} \text { gonad maturation stage, GMS) }\end{array}$ \\
\hline \multicolumn{3}{|l|}{$\begin{array}{l}\text { Sampling } \\
\text { ketiga } \\
\text { The third } \\
\text { sampling }\end{array}$} \\
\hline & $\begin{array}{c}\text { Ikan uji mencapai kisaran panjang } 6-7 \mathrm{~cm} \\
\text { The test fish has reached } 6-7 \mathrm{~cm} \text { in standard } \\
\text { length }\end{array}$ & $\begin{array}{l}\text { Gonad betina umur ikan tiga bulan, oogonia } \\
\text { sudah semakin jelas, mayoritas tampak } \\
\text { heksagonal (TKG-II) } \\
\text { The female gonads at three months old, oogonia more } \\
\text { clear and most of hexagonal form ( } 2^{\text {nd }} \mathrm{GMS} \text { ) }\end{array}$ \\
\hline \multicolumn{3}{|l|}{$\begin{array}{l}\text { Sampling } \\
\text { keempat } \\
\text { The fourth } \\
\text { sampling }\end{array}$} \\
\hline & $\begin{array}{c}\text { Ikan uji mencapai kisaran panjang } 7-8 \mathrm{~cm} \\
\text { The test fish has reached } 7-8 \mathrm{~cm} \text { in standard } \\
\text { length }\end{array}$ & $\begin{array}{l}\text { Gonad betina, umur empat bulan oosit tampak } \\
\text { jelas, ada beberapa yang sudah terdapat granula } \\
\text { (TKG-II-III) } \\
\text { The female gonads at four months old, oocyte clearly } \\
\text { shown and some had research stage II-III GMS }\end{array}$ \\
\hline
\end{tabular}


Tabel 1. Lanjutan

Table 1. Continued

\begin{tabular}{|c|c|c|}
\hline \multirow{2}{*}{$\begin{array}{l}\text { Pengamatan } \\
\text { Observation }\end{array}$} & \multicolumn{2}{|c|}{$\begin{array}{l}\text { Perkembangan ikan dan gonad ikan nilem all female } \\
\text { Gonadal and fish development of all female bonylip barb }\end{array}$} \\
\hline & $\begin{array}{l}\text { Ikan sebelum diambil gonad } \\
\text { Fish before gonad taken }\end{array}$ & $\begin{array}{l}\text { Gonad ikan all female setelah difiksasi } \\
\text { acetocarmin } \\
\text { All female gonad after fixated with acetocarmin }\end{array}$ \\
\hline $\begin{array}{l}\text { Sampling } \\
\text { kelima } \\
\text { The fifth } \\
\text { sampling }\end{array}$ & & 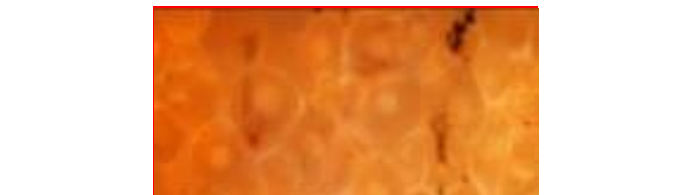 \\
\hline & $\begin{array}{c}\text { Ikan uji mencapai kisaran panjang } 8-9 \mathrm{~cm} \\
\text { The test fish has reached } 8-9 \mathrm{~cm} \text { in standard } \\
\text { length }\end{array}$ & $\begin{array}{l}\text { Gonad betina pada umur lima bulan, oosit } \\
\text { tampak jelas, ada beberapa yang sudah tampak } \\
\text { inti dengan volume lebih besar (TKG-III) } \\
\text { The female gonads at five months old, oocyte was } \\
\text { clear some have entered into stage III }\end{array}$ \\
\hline
\end{tabular}

Sampling

keenam

The sixth

sampling

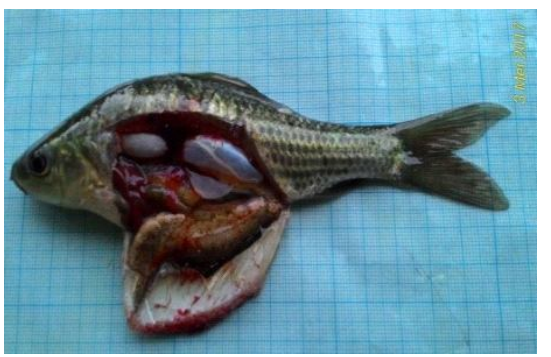

Ikan uji mencapai kisaran panjang 8-10 cm Gonad betina oosit tampak jelas, inti jelas, bahkan The test fish has reached $8-10 \mathrm{~cm}$ in standard length

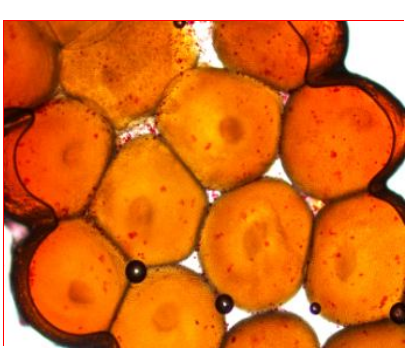

ada yang mulai migrasi ke tepi (TKG-IV awal) The female gonads at six month old, shows clear oocyte and nucleous migrate to the edge (entering stage IV)

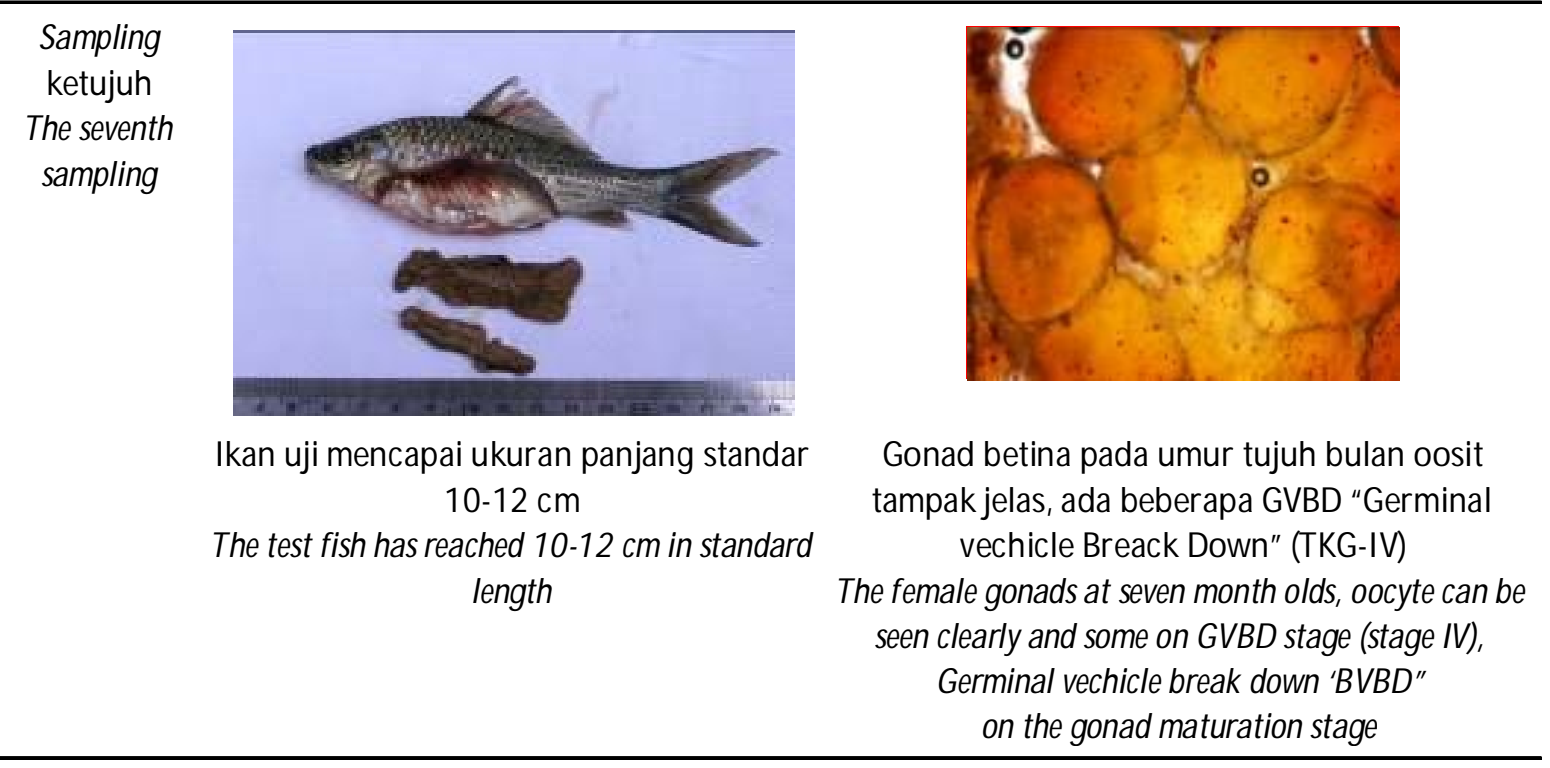


Tabel 2. Perkembangan gonad ikan nilem betina normal pada dua dan tiga bulan pengamatan

Table 2. Gonadal development of normal female bonylip barb at two and three months of observation

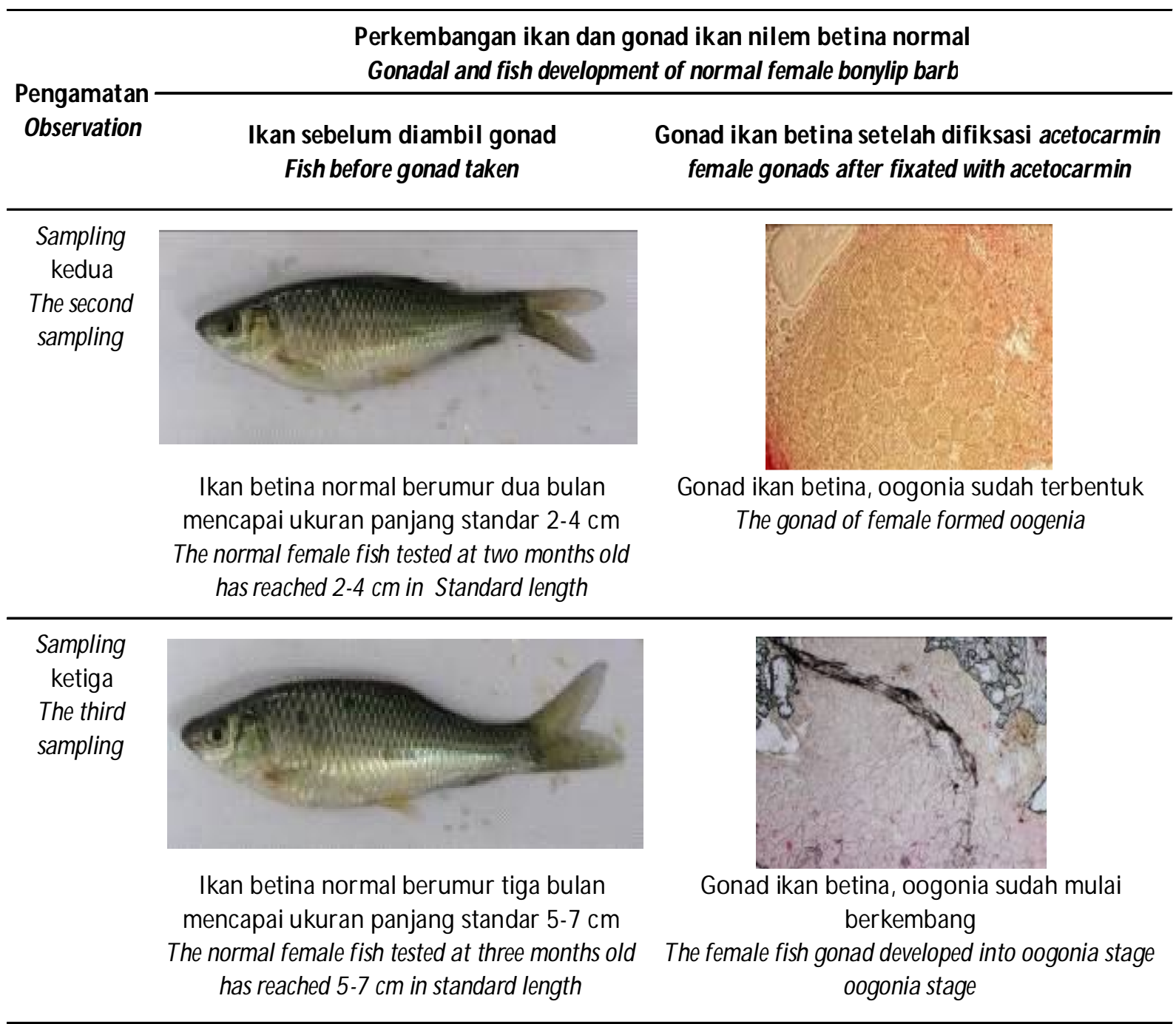

normal dan pada akhir penelitian tingkat kematangan gonad mencapai TKG-III dan IV dengan nilai IGS tertinggi sebesar $20,2 \%$ Selain itu, dari hasil pengamatan oosit sudah mencapai diameter antara 1,1-1,3 mm dan berwarna coklat mengilap dengan tekstur agak kenyal. Hasil pengukuran telur yang didapatkan dari penelitian ini sudah sesuai dengan kriteria telur tingkat matang dan merupakan persyaratan untuk proses pemijahan sistem induksi hormon (Subagja et al., 2007).

\section{Kualitas Air}

Pengukuran kualitas air dilakukan untuk menunjang kegiatan pemeliharaan karena lingkungan dapat memengaruhi pertumbuhan dan perkembangan gonad. Hasil pengukuran kualitas air selama penelitian disajikan pada Tabel 3.

Nilai yang diperoleh pada parameter kualitas air masih dalam kisaran normal untuk pemeliharaan ikan (Mallya, 2007; Boyd, 1998; Zooneveld et al., 1991).
Nilai kisaran kualitas air masih bisa ditoleransi untuk kegiatan budidaya ikan nilem, hal ini ditunjukkan dengan pertumbuhan dan perkembangan gonad pada ikan uji.

\section{KESIMPULAN}

Ikan nilem all female dapat tumbuh dan berkembang normal. Selama enam bulan pemeliharaan ikan nilem all female mengalami peningkatan panjang $(8 \%)$ dan bo bot (21\% dibandingkan dengan ikan nilem kontrol. Perkembangan gonad ikan nilem all female mencapai fase TKG-III dan IV dengan nilai IGS sebesar 20,2\%

\section{UCAPAN TERIMA KASIH}

Ucapan terima kasih disampaikan kepada Balai Riset Perikanan Budidaya Air Tawar dan Penyuluhan Perikanan karena sudah mendanai kegiatan ini melalui APBN 2010 dan kepada semua pihak yang sudah terlibat dalam kegiatan ini. 
Tabel 3. Nilai kualitas air selama pemeliharaan Table 3. Water quality variation during rearing

\begin{tabular}{lc}
\hline \multicolumn{1}{c}{ Parameter (Parameters) } & Kisaran (Range) \\
\hline $\mathrm{pH}$ & $6.6-7.2$ \\
Suhu (Temperature) $\left({ }^{\circ} \mathrm{C}\right)$ & $27.7-29.3$ \\
Oksigen terlarut (Dissolved oxigen) $(\mathrm{mg} / \mathrm{L})$ & $4.59-5.6$ \\
Nitrit (Nitrite) $(\mathrm{mg} / \mathrm{L})$ & $0.031-0.37$ \\
Nitrat (Nitrate) $(\mathrm{mg} / \mathrm{L})$ & $0.63-1.03$ \\
\hline
\end{tabular}

\section{DAFTAR ACUAN}

Ariyanto, D., Sumantadinata, K., \& Sudrajat, A.O. (2010). Diferensiasi kelamin tiga genotipe ikan nila yang diberi bahan aromatase inhibitor. J. Ris. Akuakultur, 5(2), 165-174.

Bhatta, S., Iwai, T., Miura, C., Higuchi, M., ShimizuYamaguchi, S., Fukada, H., \& Miura, T. (2012). Gonads directly regulate growth in teleosts. Proceedings of the National Academy of Sciences, 109, 11.40811.412.

Boyd, C.E., Craig, S., \& Tucker. (1998). Pond aquaculture water quality management, "Ecology of Acuaculture Ponds". USA: Kluwer Academic Publishers, p. 8-32.

Carthy, I.D., Carter, C.G., Houlihan, D.F., Johnstonet, R., \& Mitchell, A. (1996). The performance of allfemale diploid and triploid Atlantic salmon smolts on transfer together to sea water. Journal of Fish Biology, 48, 545-548.

Djajasewaka, H.J., Subagja, L., Widiyati, A., Samsudin, R., \& Winarlin. (2005). Pengaruh kadar protein terhadap produksi dan kualitas telur induk ikan nilem Osteochilus Hasselti. Seminar hasil penelitian Balai Riset Perikanan Budiaya Air Tawar. Bogor.

Effendie, M.I. (2002). Biologi perikanan. Yogyakarta: Yayasan Pustaka Nusantara, $163 \mathrm{hlm}$.

Gopal, C., Gopikrishna, G., Krishna, G., Jahageerdar, S.S., Rye, M., Hayes, B.J., Paulpandi, S., \& Kumar, D. (2010). Weight and time of onset of femalesuperior sexual dimorphism in pond reared Penaeus monodon. Aquaculture, 300, 237-239.

Hidayat, R., Carman, 0., \& Alimuddin. (2016). Perbedaan pertumbuhan ikan papuyu Anabas testudineus jantan dan betina. Jurnal Akuakultur Indonesia, 15(1), 8-14.

Junior, M.Z. (2004). Sex reversal memproduksi benih ikan jantan atau betina. Jakarta: Penebar Swadaya, $96 \mathrm{hlm}$.

Kocour, M., Linhart, O., Gela, D., \& Rodina, M. (2005). Growth performance of all female and mixed-sex common carp Cyprinus carpio. Populations in the Central Europa climatic conditions. Journal of the World Aquaculture Socienty, 36, 103-113.

Mallya, Y.J. (2007). The effects of dissolved oxygen on fish growth in aquaculture. UNU-Fisheries Training Programme, $30 \mathrm{pp}$.

Olito, C. \& Brock, I. (1991). Sex reversal of rainbow trout: creating an all female population. The Progressive Fish-Culture, 53(1), 41-44.

Pongthana, N., Penman, D.J., Baoprasertkul, P., Hussain, M.G., Shahidul, M.I., Powell, S.F., \& McAndrew, B.J. (1999). Monosex female production on the silver barb Puntius gonoinotus Bleeker. Aquaculture, 173, 247-256.

Radona, D., Asih, S., \& Sunarno, M.T.S. (2011). Penggunaan ovaprim dalam keberhasilan ovulasi, derajat penetasan dan kelangsungan hidup larva ikan nilem Osteochilus hasselti. Prosiding Seminar Nasional Perikanan, Sekolah Tinggi Perikanan. Jakarta, hlm. 102-106.

Subagja, J., Gustiano, R., \& Djajasewaka, H. (2007). Penyediaan ikan nilem Osteochilus hasseltii betina untuk mendukung produk olahan di Jawa Barat. Prosiding Seminar Internasional Perikanan 2007 "Quality management system, new technology and international marceting of fish and seafood product". Pusat Penelitian dan Pengabdian Masyarakat (P3M), Sekolah Tinggi Perikanan. Jakarta, hlm. 202-214.

Subagja, J., Hadie, W., \& Gustiano, R. (2015). Produksi ikan jantan fungsional neomale untuk membentuk populasi betina homogamet dalam industri telur ikan nilem Osteochilus hasseltii. J. Ris. Akuakultur, 10(4), 511-517.

Sutrisno, E. (1996). Pengaruh lama waktu pemberian hormon 17â-estradiol secara oral terhadap nisbah kelamin ikan nila merah Oreochromis niloticus. Skripsi. Fakultas Perikanan dan IImu Kelautan, Institut Pertanian Bogor.

Zonneveld, N.E., Huisman, J., \& Boon, M. (1991). Prinsip-prinsip budidaya ikan. Jakarta: Gramedia Pustaka Utama, $317 \mathrm{hlm}$. 